\title{
Deuteronomy 34:6: Moses' burial in text and translation
}

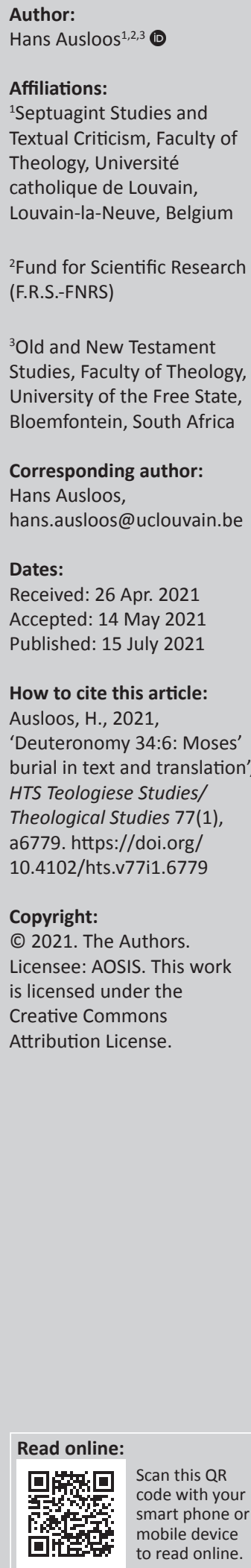

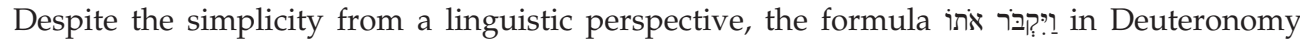
34:6 has been at the origins of a vivid discussion amongst its interpreters. Most of the time, this formula, in which an explicit subject is missing, is interpreted as having $\mathrm{YHWH}$, who is mentioned in the final part of the foregoing verse, as its subject. As such, it is YHWH who is considered as the one who buried Moses. Nevertheless, other interpretations are equally possible. In Hebrew, a third person singular verbal form can also be used in order to refer to an unidentified subject ('one'). A comparison of the Masoretic Text of Deuteronomy 34:6 to the Versiones makes clear that the latter apparently has been the interpretation of the Septuagint translator, even if one cannot be sure whether its plural verbal form $\ddot{\varepsilon} \theta \alpha \psi \alpha v$ is because of the interpretation of the Greek translator or to a different Hebrew Vorlage. Moreover, the comparison of the different textual witnesses of Deuteronomy 34:6 makes clear that a conclusive answer to

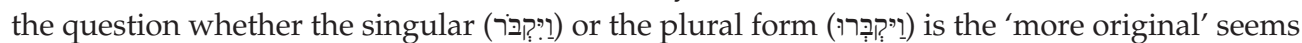
to be impossible.

Contribution: Refraining from historical-critical or theological prejudices, the present article evaluates the possibilities as to the issue who buried Moses, according to Deuteronomy 34:8. It demonstrates that on the basis of textual evidences as witnessed by the Versiones, a univocal interpretation should not be imposed to the text. Interpreting difficult Bible passages is one of the core focusses of HTS Teologiese Studies/Theological Studies.

Keywords: Deuteronomy; Moses; Masoretic Text; Septuagint; manuscripts of the Judean Desert; textual criticism.

\section{Introduction}

In a recent article on the final chapter of the Book of Deuteronomy, Serge Frolov is rather firm with regard to the question who buried Moses according to Deuteronomy 34:6; in his view, the narrator has clearly been considering $\mathrm{YHWH}$, 'the only suitable antecedent of the sentence's masculine singular predicate', as the implied subject of ר?ב? (Frolov 2014:653). ${ }^{1}$ Frolov is not an exception. Indeed, in general, one accepts that the author of Deuteronomy 34:6 did have the intention to narrate that it was YHWH who buried Moses. ${ }^{2}$ Nevertheless, the way this has been taken for granted seems not to be supported by everyone, as already a tentative comparison of some modern Bible translations of this verse makes clear. Moreover, the question, who buried Moses also seems to have occupied ancient scribes of the text, as several textual witnesses illustrate.

\section{Moses' burial according to Deuteronomy 34:6}

Following on the very concise rendering of Moses' death in Deuteronomy 34:5 ('And there, Moses, the servant of $\mathrm{YHWH}$, died in the land of Moab, according to the word of $\left.\mathrm{YHWH}^{\prime}\right)$ - it does not seem to be much more than a fait divers - verse 6 immediately continues by narrating Moses' burial. From a merely linguistic perspective, the Hebrew of the MT is not at all problematic. A verb in the

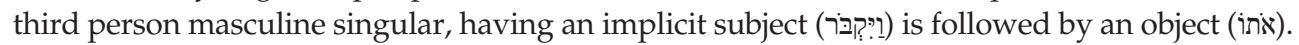

Nevertheless, despite its apparent simplicity, Bible translators seem to have (had) difficulties in translating this Hebrew formula. As the Italian adage Traduttore, traditore ('A translator is a traitor') makes clear, Bible translators - in past and present - often have to make choices in translating a

1.I am well aware of the centuries-old discussion on the authorship of Deuteronomy 34 . See, in this respect, a.o., the surveys of biblical scholarship by García López (1994:47-51), Brettler and Römer (2000:402-404), Frevel (2001:210-213), Yoo (2012:423-425) and Otto (2017:2272-2277). Within the context of this article, this topic can be left out of consideration.

2.See, for example, most recently Otto (2017:2281): 'Dass Mose von JHWH begraben worden sei, ist auf die Aussage der nachexilischen Fortschreibung in Dtn 34,6b hin formuliert, niemand kenne bis zum heutigen Tage Moses Grab'. This 'nachexilischen Fortschreibung liegt in Dtn 34,6 eine deuteronomistische Begräbnisnotiz "und sie begruben ihn im Land Moab" zugrunde' (Otto 2017:2278). 
text from its source language to a target language. A brief survey of some English Bible translations of Deuteronomy 34:6 illustrates this issue.

First of all, and typical of a first category of translations, one can refer to the interpretation - a translator also is an interpreter - of the King James Version (KJV):

${ }^{5}$ So Moses the servant of the LORD died there in the land of Moab, according to the word of the LORD. ${ }^{6}$ And he buried him in a valley in the land of Moab.

As such, the KJV seems to give a literal rendering of the Hebrew original ${ }^{3}$ : a third person masculine singular form of the verb ('buried'), making explicit - this is necessary in English - the implicit subject - here translated as 'he', and followed by an object ('him'). The context makes clear that it is Moses who is buried. Because of the fact that YHWH has been mentioned in the final part of v. 5, the translator of the KJV at least suggests that the subject 'he' refers to YHWH as the subject of the verb 'to bury': he (YHWH) buried him (Moses). In theory, the translator also could have had a human subject in mind. However, because of the context, that does not seem to be plausible, all the more because the KJV does not make use of a capital when speaking about God. At this point, the KJV can be distinguished from the more recent New American Standard Bible (NASB):

${ }^{5}$ So Moses the servant of the LORD died there in the land of Moab, in accordance with the word of the Lord. ${ }^{6}$ And He buried him in the valley in the land of Moab.

Contrary to the KJV, the translators of the NASB make the rendering of Deuteronomy 34:6 unambiguous: in using a capital ('He'), it becomes clear to the reader that they consider YHWH as the unidentified subject of the verb.

The New International Reader's Version (NIRV) - just to mention another example - goes a step further. In making the subject of the verb explicit - which is not the case in the MT there can be no doubt regarding the question who actually has buried Moses:

${ }^{5}$ Moses, the servant of the LORD, died there in Moab. It happened just as the LORD had said. ${ }^{6}$ The LORD buried the body of Moses in Moab.

Thus, in one or another way, the Bible translations that have been referred to until now - KJV, NASB and NIRV presuppose or make explicit that YHWH should be

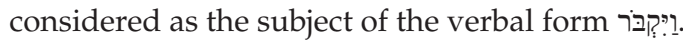

Notwithstanding this general tendency in current Bible translations, there are also translations that interpret this verse in a completely different way, and so does the New Revised Standard Version Catholic Edition (NRSVCA), for example, when it renders Deuteronomy 34:5-6 as follows:

${ }^{5}$ Then Moses, the servant of the Lord, died there in the land of Moab, at the Lord's command. ${ }^{6} \mathrm{He}$ was buried in a valley in the land of Moab.

3.On the necessary distinction and complementarity between the terms 'literal', 'free' and 'faithful' in characterising a (Biblical) translation, see Lemmelijn (2007:1-32) and 'faithful' in characterisin
In translating In a passive way as 'he was buried', the NRSVCA seems to avoid accentuating that YHWH has buried Moses. In theory, this rendering of the verbal form ?ִ (wayyiqbōr) is not impossible, at least if one makes abstraction of the Masoretes' vocalisation. The consonants ויקבר equally allow another vocalisation, namely as a third person singular

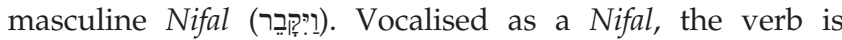
expressing a passive function. As such, it is used, for example, in Deuteronomy 10:6: Aaron died, 'and he was buried (1) (1) there'. If ויקבר in Deuteronomy 34:6 is vocalised as a Nifal, in translation, the pronoun 'he' is not referring to the subject of the verb, but to its implied object: 'he [i.e. Moses] was buried'. Notwithstanding the fact that this vocalisation of the verb as such is possible, it is not plausible in Deuteronomy 34:6, because of the accusative is that follows it.

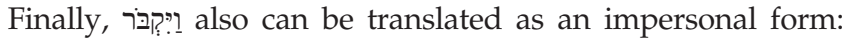
'(some)one buried Moses'. This rendering, which, as the foregoing one, keeps the reader guessing with regard to the subject of the verb - even if it, at least, suggests a human subject and seems to exclude a divine one - does not seem to have found its way in modern English Bible translations. ${ }^{4}$ The absence of this translation or interpretation is rather strange, all the more because a third personal singular verbal form is not at all unusual in Hebrew to refer to an indefinite subject (Gesenius \& Kautsch 1962:§144d; Joüon \& Muraoka 1993:§155b; Rabin 1962:62-67). ${ }^{5}$ This also seems to have been the case with regard to the verb קבר, as 2 Kings 21:26 testifies. Here, in the pericope narrating the burial of King Amon, one

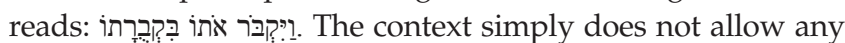
other rendering than an indefinite one ('one buried him in his tomb'). ${ }^{6}$

In sum, two main tendencies can be seen with regard to the rendering of Deuteronomy 34:6: the majority of translators or interpreters consider (explicitly) $\mathrm{YHWH}$ as the subject of the verb וּ?: He (YHWH) buried him (Moses). Others seem to avoid a burial by YHWH and to suggest that Moses has been buried by humans. Here, at least theoretically, the subject can be translated in an indefinite way ('one buried him'); a passive rendering - which implies a different vocalisation however ('he has been buried'), is rather problematic because of the use of the object

\section{Who buried Moses in the Versiones?}

The foregoing overview is illustrative to the fact that the Biblical text, sometimes, seems to confront its readers and interpreters with problems that largely surpass the linguistic level. The problems which readers have with regard to

4.See, however, for example, the Dutch Petrus Canisiusvertaling: ${ }^{5}$ Toen stierf Mozes, de dienaar van Jahweh, in het land Moab, zoals Jahweh het hem had gezegd. ${ }^{6}$ Men begroef hem in de vallei van het land Moab'. See also Schwertner (1972:26): 'und man begrub ihn'.

5.According to Rabin (1962:62-65), a Hebrew third person singular verbal form with indefinite subject can be found in Genesis 19:17; 43:34; 50:26, Exodus 18:16, indefinite subect (18:26; 22:38, 2 Kings 21:26, Isaiah 7:24; 15:5; 25:9; 65:8; 68:35, Amos 6:12, Habakkuk 2:6,

6.It has to be noted, however, that, as BHS indicates, several Hebrew manuscripts

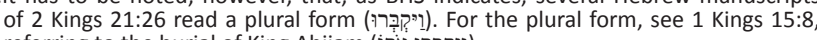

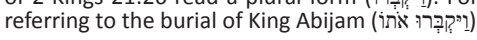


Deuteronomy 34:6 rather seem to be theological or exegetical than being merely linguistic. Moreover, this discussion does not seem to be a recent one (Houtman 1978:73-77).

Some traces of this discussion can already be found in the most ancient manuscripts of Deuteronomy 34. Even if the oldest complete manuscript of the Hebrew Bible - the Leningrad codex, dating, however, from $1208 \mathrm{CE}$ - reads the singular form, other texts do not follow this reading. First of all, reference can be made to the Septuagint (LXX) translation of the verse:

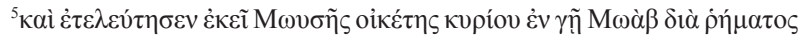

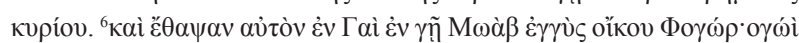

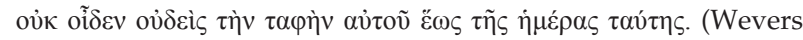
2006:374-375)

${ }^{5}$ And there, Moses, the servant ${ }^{7}$ of the Lord, died in the land of Moab through the word of the Lord. ${ }^{6}$ And they/one buried him in Gai, in the land of Moab, near the house of Phogor. And no one knows his grave to this day. [Author's own translation]

In addition to some variant readings with regard to the location of Moses' burial, contrary to the MT, the LXX reads a plural verbal form where the MT has a singular one: кaì

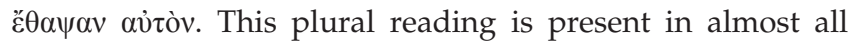
extant manuscripts of the LXX. ${ }^{8}$ The New English Translation of the Septuagint (NETS) (Peters 2007:173) translated this Greek formula literally as 'And they buried him', as does the Spanish translation ('Y lo enterraron') (Fernández Marcos, Spottorno Díaz-Caro \& Canãs 2008:448). The French translation - La Bible d'Alexandrie - however, translates $\check{\varepsilon} \theta \alpha \psi \alpha v$ in a singular way, as having an indefinite subject: ' $E t$ on l'ensevelit' (Dogniez \& Harl 1992:355). Contrary to the MT, in which the Hebrew only allows a single person interpretation, in Greek both translations are possible, as Margolis (1907:246) already had argued. Besides being used as a real third person plural, 'die 3 plur. wird eben im Griechischen gerade so wie im Hebräischen zum Ausdruck des unbestimmten Subjektes gebraucht'.

Because of the plural form in the LXX, it is not plausible that YHWH should be considered as the one who buried Moses. During the history of research, this variant reading of the LXX has often been used as an argument in favour of the anti-anthropomorphic bias of the LXX's translator (Fritsch 1943:53; Den Hertog, Labahn \& Pola 2011:601; Wevers 1995:559, 1997:88). ${ }^{9}$ However, one has to be very careful in making the LXX's translator responsible for so-called theological or exegetical or ideological accents of the translation when different from the MT (Ausloos 2017:249).

On the one hand, in light of what has been said, the rendering

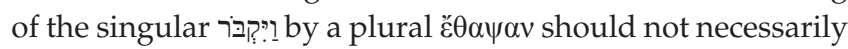
be interpreted as a variant reading: if the translator has interpreted the unvocalised ויקבר as having an indefinite

7.NETS (Peters 2007:173) translated oiketns as 'domestic'. On the use of this term, see in particular Dogniez and Harl (1992:355).

8.Amongst all extant textual witnesses, only minuscule 500 (11th -12 th century CE) has the singular form ( $\varepsilon \theta \alpha \psi \varepsilon v)$; see Wevers (2006:374)

9.On anti-anthropomorphisms in the LXX of Deuteronomy, see Ausloos (2020a: 163-177) and Ausloos (2020b:187). subject-as Rabin (1962:62-67) had argued, this is not unusual, even if he does not consider Deuteronomy 34:6 as witnessing to this phenomenon - a third person plural Greek equivalent was an excellent choice. In order to make a sound conclusion in this regard, a detailed analysis of the translation technique of LXX Deuteronomy as to the rendering of indefinite Hebrew forms in Greek could be helpful. ${ }^{10}$

On the other hand, it is also possible that the LXX translator was translating a Vorlage diverging from the MT. Actually, thanks to the discoveries in the Judean Desert, a Hebrew manuscript has been discovered which, precisely as the LXX, has been reading a plural form. So, 4QDeut ${ }^{1}$ reads ויקברו, as do some more recent manuscripts of the Samaritan Pentateuch, Targum Neofiti and the Fragmentary Targum. Moreover, contrary to what generally is accepted, it cannot be excluded that also MasDeut has read a plural form (Ausloos 2020c:605-609). Also in Hebrew, a third person plural is very frequently used to express an indefinite personal subject (Gesenius \& Kautsch 1962: 1144 f). Thus, these manuscripts do at least suggest that the reading of the LXX is not because of the interpretation of the translator, but rather the result of a divergent Vorlage (Otto 2017:226), even if, as said before, a third person plural Greek form can be used to express an indefinite subject as implied in a third person singular Hebrew verbal form.

\section{Deut 34:6 in text-critical perspective}

From a text-critical perspective, one is confronted with the intriguing question: which reading - ויקברו or - has to be considered as the more original one? ${ }^{11}$ However, this is a very difficult issue, all the more because both possibilities have serious pros and contras.

Firstly, the singular form ויקבר is more original. Those who are in favour of the originality of ויקבר will mainly argue that the author of Deuteronomy 34 was consciously willing to accentuate Moses' extraordinary status in considering YHWH as the one who buried Moses. ${ }^{12}$ For, as Deuteronomy 34:10 accentuates: 'In Israel, never a prophet has raisen like Moses, whom YHWH knew face to face'. Moreover, the fact that Deuteronomy 34:6 accentuated that Moses' grave is not known 'until this day' and that Moses, despite his 120 years, did still have all his forces and vitality - 'his eye was not dim and his vigour was not fled' (Dt 34:7) - all these elements seem to be mentioned to convince the reader of

10.See, in this respect, the remark of Fernandez Marcos (2001:28): 'Prior to any study of the theology of the translation or any induction about the possible different Hebrew Vorlage that the translators had in front of them, one has to ask oneself to what extent the divergences from the Hebrew text are conditioned by the linguistic possibilities of Greek as compared to Hebrew. These requirements of the linguistic expression no doubt have theological consequences, but primarily they are linguistic and do not in themselves imply a concrete exegetic tendency on the part of the translators'.

11.On the issue of the 'more original variant', see Cook (1992:521): 'The definition "more original" is a more neutral term. It acts only as an indication that a reading is older and could be used in order to describe variants'. See also Lemmelijn (2009:20-22).

12.See Frolov (2014:653): 'By taking care of it and thus preventing desecration of the body by animals or humans, YHWH - the only suitable antecedent of the sentence's masculine singular predicate - acts as Moses' loving relative (Gn 23, 2 Sm 21:1-14) or loyal ally (1 Sm 31:8-13)'. 
Moses' extraordinary nature and to highlight the mysterious character of his death and burial. In later Jewish interpretation of the text, this extraordinary status has even been further developed. For example, instead of dealing with Moses' death and burial, in his Antiquitates Judaicae (IV, 323-326), Flavius Josephus says that in Moses' final moments, a cloud came over him, and that he disappeared $(\dot{\alpha} \varphi \alpha v i \zeta \varepsilon \tau \alpha \iota)$ in a valley. ${ }^{13}$ According to Josephus, in the final chapter of Deuteronomy, Moses wrote that he died a 'normal' death, in order to avoid that the Israelites would say that he directly returned to God, because of his extraordinary virtue (Thackeray 1961:632). In his De Vita Mosis $(19,16)$, Pseudo-Philon (1st - 2nd century CE) does not only explicitly mention that Moses died. Moreover, he accentuates that God himself buried Moses 'on a high place' (Jacobson 1996:193). Equally, the fifth book of Memar Marqah ('The Teaching of Marqah'), probably dating from the 2nd to 4th centuries CE, accentuates that Moses was buried by God ( $(4)$, referring to and quoting Deuteronomy 34:6 (MacDonald 1963:208). Also the later Jewish tradition for example, Midrash Petirat Moshe - accentuates that Moses has been buried by God. ${ }^{14}$

Nevertheless, good arguments can be given as well in saying that the Hebrew author of Deuteronomy 34:6, by using the singular form accentuating a divine burial of Moses. Although the text does not mention that Moses is accompanied by some Israelites when he climbs up Mount Nebo, the author neither explicitly mentions that Moses was alone when climbing the mountain (Dt 34:1). So, it would equally be possible that Moses, according to the author, has been buried by some of his compatriots or by someone else who found his dead body. Anyway, the singular form be interpreted as having an indefinite subject ('one'), as does the plural form and someone buried him. In this interpretation, the particle

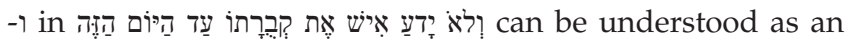
adversative one: 'someone buried him [somewhere] in a valley in the land of Moab, opposite Beth Peor; but until today, nobody knows his grave'.15

The accentuation of Moses' burial by God, or at least the possibility to interpret the singular form as referring to a divine subject, could have offended some readers of the text,

13. Being disappeared into a ravine is rather odd, because the verb o $\phi a v i \zeta \omega^{\prime}$ presupposes a move to another world. Josephus uses the verb $\alpha \dot{\phi} \alpha v i \zeta \omega$ also for

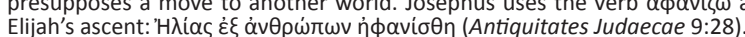

14.In order to solve this problem, medieval tradition, as, for example, found in the Palaea Historica (between 9th and 12th centuries) has suggested that Moses' body has been buried by the angel Michael, who 'removed the body of Moses to a place has been buried by the angel Michael, who 'removed the body of Moses to a place
ordered by Christ our God, [and no one saw Moses' tomb]' (Adler 2013:647) - The text between brackets is found in a second manuscript of the text (Ms O), supplementing some lacunae in Ms V (Adler 2013:585).

In characterising the third person plural reading as an exegetical interpretation McCarthy (2007:104) evaluated the third person singular form of the MT as more original. Moreover, she refers to the 'midrashic expansion of $\mathrm{T}^{\text {s' }}$ that 'clearly illustrates the tradition that it was none other than God who buried Moses' (McCarthy 2007; Deuteronomy 168*).

15.Theoretically, from a linguistic point of view, there is another translation possible, which, however, has not been echoed in any modern translation: the preposition א with suffix can also be used - albeit rather exceptionally - reflexively. So, one could also translate 'he buried himself'. It is possible that the author intended to narrate that Moses had withdrawn into a cave in order to die there. This interpretation encounters a difficulty with regard to the surrounding context. After ill, in Deuteronomy 34:5, it was already told that Moses died. How can he have all, in Deuteronomy $34: 5$, it was
buried himself in the next verse? in particular because of the anthropomorphic depiction of God, being presented as a gravedigger who occupies himself with the burial of a human being, albeit Moses, the prophet par excellence. In particular against the background of Leviticus 21:1 and Numbers 6:6, both being texts that consider a dead body as unclean, one argues that some scribes (as it is witnessed in 4QDeut', MasDeut[?] and some manuscripts of the SamP) may have changed the original reading ויקבר into ויקברו, perhaps in harmonising the verse with Joshua 24:30, 33 , in which one reads that 'one' buried Joshua and Aaron's

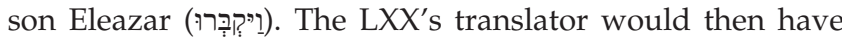
been dependent on this Hebrew tradition.

Secondly, the plural form ויקברו is more original. If the plural form (as in 4 QDeut ${ }^{1}$ and the LXX) has to be considered the more original - and if so, only a human subject can be understood - by modifying the plural into a singular form, a scribe or redactor has aimed at making the text more mysterious: in using a singular form, the text no longer is univocal, because no definite answer can be given to the question, who buried Moses. Because of the fact that ? both allows a divine as a human subject, the scribe would have made the text more ambiguous and mysterious. If so, we encounter a scribe or redactor who intended at least to suggest that Moses has been buried by YHWH. As the brief survey of modern translations has made clear, this scribe or redactor has not at all made it easier for modern Bible translators and interpreters, who mainly base themselves on the singular version of the MT.

\section{Conclusion}

Despite its simplicity from a linguistic perspective, the formula

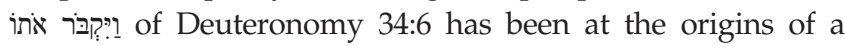
vivid discussion amongst its interpreters. This discussion has mainly been nourished by theological arguments, that either accentuated the extraordinary character of Moses (because he, as the only one, has been buried by $\mathrm{YHWH}$ ), or the impossibility that $\mathrm{YHWH}$ could be presented as burying a human person (anti-anthropomorpism). As to the reading of the MT, however, both subjects - a human and a divine - are possible.

Therefore, a sound answer to the question whether the

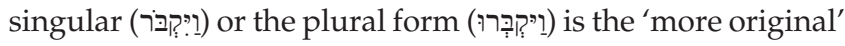
can hardly be given. ${ }^{16}$ If the singular reading would have been the more original one - even if there is no particular textual reason that necessitates to accept that the author was explicitly considering YHWH as the one who buried Moses - then the plural form (both in Hebrew and, probably on this base, also in Greek) aimed at making a divine subject impossible. On the other hand, if the plural reading has been the more original one than the scribal intervention, in omitting the final -1 , this has resulted in an ambiguous interpretation: both a human and a divine subject are possible. Later tradition, then, has mainly focussed on a theological interpretation, thus emphasising the extraordinary character of Moses as being buried by YHWH.

16.Contrary to Otto (2017:2281), who considers the singular reading, with $\mathrm{YHWH}$ as subject, to be the lectio difficilior. See equally Otto (2017:2269). 


\section{Acknowledgements Competing interests}

The author declares that he has no financial or personal relationships that may have inappropriately influenced him in writing this article.

\section{Author's contributions}

H.A. is the sole author of this research article.

\section{Ethical considerations}

This article followed all ethical standards for research without direct contact with human or animal subjects.

\section{Funding information}

This work is based on research supported by the F.R.S.-FNRS (Belgium).

\section{Data availability}

Data sharing is not applicable to this article as no new data were created or analysed in this study.

\section{Disclaimer}

The views and opinions expressed in this article are those of the author and do not necessarily reflect the official policy or position of any affiliated agency of the author.

\section{References}

Adler, W., 2013, 'Palaea Historica ("The Old Testament history"),' in R. Bauckam J.R. Davila \& A. Panaytov (eds), Old Testament Pseudepigrapha: More noncanonica scriptures, pp. 585-672, Eerdmans, Grand Rapids, MI.

Ausloos, H., 2017, 'Sept défis posés à une théologie de la Septante', in L.C. Jonker, G.R. Kotzé \& C.M. Maier (eds.), Congress volume Stellenbosch 2016 (VTSup, 177), pp. 228-250, Brill, Leiden.

Ausloos, H., 2020a, 'You saw no form when YHWH spoke to you at Horeb' (Deut 4 15), Antianthropomorphisms in the Greek Deuteronomy', in J. Cook \& M. Rösel (eds.), Toward a theology of the Septuagint - Stellenbosch Congress on the Septuagint, 2018 (SBLSCS, 74), pp. 163-177, SBL, Atlanta, GA.

Ausloos, H., 2020b, 'Human activities attributed to God in Deuteronomy MT and LXX', in C. Eberhart, M. Karrer, S. Kreuzer \& M. Meiser (eds.), Tempel, Lehrhaus, Synagoge: Orte jüdischen Lernens und Lebens - Festschrift für Wolfgang Kraus, pp. 181-192, Ferdinand Schöningh, Paderborn.

Ausloos, H., 2020c, 'A fresh look at Deut 34, 6 (Mas Deut)', Biblica 101(4), 602-611.

Ausloos, H., 2021, 'Translation technique', in A. Salvesen \& T.M. Law (eds.), Oxford handbook of the Septuagint, pp. 165-179, Oxford University Press, Oxford.

Brettler, M.Z. \& Römer, T., 2000, 'Deuteronomy 34 and the case for a Persian Pentateuch', Journal of Biblical Literature 119(3), 401-419. https://doi. org/10.2307/3268406
Cook, J., 1992, 'Questions of textual criticism: To reconstruct or not?', in AIBI: Bible et Informatique. Interrprétation, herméneutique, compétence informatique, Tübingen, 1991, pp. 515-522, Champion-Slatkine, Paris.

Den Hertog, C., Labahn, M. \& Pola, T., 2011, 'Deuteronomion/Deuteronomium', in M. Karrer \& W. Kraus (eds.), Septuaginta Deutsch: Erläuterungen und Kommentare zum griechischen Alten Testament, Band 1: Genesis bis Makkabäer, pp. 523-601, Deutsche Bibelgesellschaft, Stuttgart.

Dogniez, C. \& Harl, M., 1992, Le Deutéronome (La Bible d'Alexandrie, 5), Cerf, Paris.

Fernández Marcos, N., 2001, The Septuagint in context: Introduction to the Greek versions of the bible, Brill, Boston.

Fernández Marcos, N., Spottorno Díaz-Caro, V. \& Canãs, R, 2008, La Bibla Griega Septuaginta, I: El Pentateuco (Biblioteca Estudios Bíblicos, 125), Sigueme, Salamanca.

Frevel, C., 2001, 'Ein vielsagender Abschied, Exegetische Blicke auf den Tod des Mose in Dtn 34, 1-12', Biblische Zeitschrift 45(2), 209-234. https://doi. org/10.1163/25890468-04502004

Fritsch, C.T., 1943, The anti-anthropomorphisms of the Greek Pentateuch, University Press, Princeton, NJ.

Frolov, S., 2014, 'The death of Moses and the fate of source criticism', Journal of Biblical Literature 133(3), 648-660. https://doi.org/10.1353/jbl.2014.0034

García López, F., 1994, 'Deut 34, Dtr history and the Pentateuch', in F. García Martínez, A. Hilhorst \& J.T.A.G.M. Van Ruiten, A.S. Van der Woude (eds.), Studies in Deuteronomy in honour of C.J. Labuschagne on the occasion of his 65 th birthday, pp. 47-61, (VTSup, 53), Brill, Leiden.

Gesenius, W. \& Kautzsch, E., 1962, Wilhelm Gesenbius' hebräische Grammatik, Olms, Hildesheim.

Houtman, C., 1978, 'De dood van Moses, de knecht des Heren, Notities over en naar aanleiding van Deuteronomium 34:1-8', in De Knecht, Studies rondom DeuteroJesaja door collega's en oud-leerlingen aangeboden aan Prof. Dr. J.L. Koole, pp. 72-82, Kok, Kampen.

Jacobson, H., 1996, A commentary on Pseudo-Philo's Liber Antiquitatum Biblicarum 2 volumes (AGJU, 31), Brill, Leiden.

Joüon, P. \& Muraoka, T., 1993, A grammar of Biblical Hebrew, Part three: Syntax (SubBi, 14/2), Ponticifio Istituto Biblico, Rome.

Lemmelijn, B., 2007, 'Free and yet faithful, On the translation technique of LXX Exod 7:14-11, 10', JNSL 33(1), 1-32.

Lemmelijn, B., 2009, A plague of texts? A text-critical study of the so-called 'plagues narrative' in Exodus 7:14-11:10 (OtSt, 56), Brill, Leiden.

MacDonald, J., 1963, Memar Marqah - The teaching of Marqah (BZAW, 184), Töpelman, Berlin.

Margolis, M.L., 1907, Studien im griechischen alten Testament, ZAW 27(2), 212-270. https://doi.org/10.1515/zatw.1907.27.2.212

McCarthy, C., 2007, אלה הדברים - Deuteronomy (BHQ, 5), Deutsche Bibelgesellschaft, Stuttgart.

Otto, E., 2017, Deuteronomium 23,16-34, 12 (HTKAT), Herder, Freiburg im Breisgau.

Peters, M.K.H., 2007, 'Deuteronomion', in A. Pietersma \& B.G. Wright (eds.), A new English translation of the Septuagint and the other Greek translations traditionally included under that title, pp. 141-173, Oxford University Press, New York.

Rabin, C., 1962, 'The ancient versions and the indefinite subject', Textus 2(1) 60-76. https://doi.org/10.1163/2589255X-00201006

Schwertner, S., 1972, 'Erwägungen zu Moses Tod und Grab in Dtn 34:5.6*', ZAW 84(1) 25-46. https://doi.org/10.1515/zatw.1972.84.1.25

Thackeray, H.St. J., 1961, Josephus with an English translation in nine volumes, IV Jewish antiquities books I-IV (Loeb Classical Library), William Heinemann Harvard University Press, London.

Wevers, J.W., 1995, Notes on the Greek text of Deuteronomy (SBLSCS, 39), Scholars Press, Atlanta, GA.

Wevers, J.W., 1997, 'The LXX translator of Deuteronomy', in B. Taylor (ed.), IX congress of the International organization for Septuagint and Cognate studies - Cambridge, 1995 (SBLSCS, 45), Sholars Press, Atlanta, GA.

Wevers, J.W., 2006, Deuteronomium (Septuaginta Vetus Testamentum Graecum Auctoritate Academiae Scientiarum Gottingensis editum, III/2), Vandenhoeck \& Ruprecht, Göttingen.

Yoo, P.Y., 2012, 'The four Moses death accounts', Journal of Biblical Literature 131(3), 423-441. https://doi.org/10.2307/23488247 